\title{
Changes in Organic Acid Contents and Related Metabolic Enzyme Activities at Different Stages of Growth of Two Tangerine Cultivars
}

\author{
Worawaran Roongruangsri ${ }^{1}$, Nithiya Rattanapanone ${ }^{1}$, Noppol Leksawasdi ${ }^{2} \&$ Danai Boonyakiat ${ }^{1}$ \\ ${ }^{1}$ Postharvest Technology Research Institute, Chiang Mai University, Chiang Mai, Thailand \\ ${ }^{2}$ Faculty of Agro-Industry, Chiang Mai University, Chiang Mai, Thailand \\ Correspondence: Worawaran Roongruangsri, Postharvest Technology Research Institute, Chiang Mai University, \\ Chiang Mai 50200, Thailand. E-mail: worawaran@rmutl.ac.th
}

Received: August 30, 2012 Accepted: September 19, 2012 Online Published: November 15, 2012

doi:10.5539/jas.v4n12p276 URL: http://dx.doi.org/10.5539/jas.v4n12p276

\begin{abstract}
Citric acid accumulation and decline and its related enzymes were studied at different stages of growth of two tangerine cultivars, 'Sai Num Phueng' and 'See Thong'. Citric acidcontent increased to the peak at early growth stage (16-24 weeks after full bloom, WAF), then decreased rapidly for 28-34 WAFand slightly decreased during maturation (35-37 WAF). 'Sai Num Phueng' had higher citric acid content than 'See Thong'. The activities of enzymes citrate synthase in mitochondrial fraction, aconitase in both mitochondrial and cytosolic fractions and NADP-isocitrate dehydrogenase (IDH) in cytosolic fraction were determined. The changes in these three enzyme activities followed similar patterns in both cultivars. For 16-24 WAF, citrate synthase activity increased and aconitase activity decreased in mitochondrial fraction, which accelerated the increasingin citric acid content of both cultivars. Therefore, citrate synthase and aconitase enzymes in mitochondria were essential forcitric acid accumulation at early growth stage. During 28-34 WAF, aconitase and NADP-IDH activities in cytosolic fraction were induced with the concomitant decrease of citric acid content. Thus, aconitase in cytosol played a key role in the reduction of citric acid. NADP-IDH could be consisted with aconitase for enhancement the reduction of citric acid in cytosol. Aconitase activity could account for the difference in citric acid contentbetween 'Sai Num Phueng' and 'See Thong'. It was also found that the level of citrate synthase activity was quite similar between the two cultivars but aconitase activity was lower in 'Sai Num Phueng' than in 'See Thong'.
\end{abstract}

Keywords: tangerine fruit, citric acid, citrate synthase, aconitase, NADP-isocitrate dehydrogenase

\section{Introduction}

Tangerine fruit (Citrus reticulate Blanco) is a non-climacteric subtropical fruitof high commercial value in the citrus fruit market (Ting \& Attaway, 1971). It comprised about 20 percent of the total of world citrus output and China leads its production (Ladaniya, 2008). In Thailand, tangerine was providing 80 percent of the national fruit production. 'Sai Num Phueng' was the major cultivar followed by 'See Thong' (Office of Comercial Affairs Chiang mai, 2008).

Organic acids played an important role in fruit taste, flavor and organoleptic quality (Lobit et al., 2003). In mandarin, citric acid was the major organic acid, accounting for $75-80 \%$ of the total organic acids while malic acid was the next most abundant (Baldwin, 1993). Since the flavor quality of citrus fruit was influenced by citric acid (Iglesias et al., 2007), citric acid metabolism, resulting in citric acid accumulation and reduction, was very interesting from the point of view of physiology and commercial value (Ladaniya, 2008). High or low citric acid content often reduced the citrus fruit quality, but the moderate concentration of citric acid could make the fruit more palatable (Iglesias et al., 2007).

Citric acid synthesis took place in the mitochondria of juice sac cells, and was part of the tricarboxylic acid (TCA) cycle (Sadka et al., 2001). The six-carbon citric acid was formed when citrate synthase condensed the two-carbon molecule acetyl-CoA with the four-carbon molecule oxaloacetic acid (Ting \& Attaway, 1971). Citric acid was either transported to vacuoles, or degraded by aconitase catalysis of the reversible isomerization of isocitric acid in the cytosol (Sadka et al., 2000a). The enzymes potentially involved in fruit 
citric acid accumulation and reduction included citrate synthase (EC 2.3.3.1) (Sadka et al., 2001), aconitase (EC 4.2.1.3) (Sadka et al., 2000a) and NADP-IDH (EC 1.1.1.42) (Sadka et al., 2000b).

Organic acid metabolism has been studied in other fruits, such as sweet lime and sour lemon (Sadka et al., 2000a), pineapple (Saradhuldhat \& Paull, 2007), loquat (Chen et al., 2009), melon (Tang et al., 2010) and grape(Sweetman et al., 2009). The data was notably missing any information on the tangerine fruit. Moreover, the regulation and control for citric acid in citrus fruit was not clearly clarified and understood (Sadka et al., 2000a). The objective of this study was to determine the role of citric acid metabolizing enzymes in the control of citric acid accumulation and reductionat different stages of growth of two tangerine cultivars, "Sai Num Phueng" and "See Thong".

\section{Materials and Methods}

\subsection{Fruit Materials}

Fruit from tangerine trees cv. 'Sai Num Phueng' and 'See Thong', approximately 10 years old, grown at the Chiang Mai Thanathon Co., Ltd., located at Chiang Mai Province, Northern Thailand, were used. In both tangerine cultivars, the young fruit of the same size (about $0.2 \mathrm{~cm}$ diameter at the equatorial axis) were tagged after full bloom of seven trees for each cultivar and followed throughout fruit development. The tangerine fruit were began to pick at $16 \mathrm{WAF}$ and continued every 4 weeks until $32 \mathrm{WAF}$, after which fruit were harvested every week until $37 \mathrm{WAF}$. At each sampling, 12-18 tagged fruits of each cultivar were collected and divided into three replicates with 4-6 fruits per replicate depending on the fruit size. Each fruit was carefully dissected into pulp and peel. Then, the pooled pulp and peel of each replication were immediately frozen in liquid $\mathrm{N}_{2}$ and stored at $-70^{\circ} \mathrm{C}$ until analysis.

\subsection{Measurement of Titratable Acidity (TA) and Total Soluble Solids (TSS)}

TA was determined by titration of $5 \mathrm{ml}$ of juice with $0.1 \mathrm{M} \mathrm{NaOH}$ until $\mathrm{pH} 8.1$ and expressed as percentage of citric acid per $100 \mathrm{~g}$ juice (AOAC, 2005). TSS was determined using a digital refractometer (Model PR-101, ATAGO, Japan) (AOAC, 2005). TA and TSS were determined in triplicate for each replication and averaged.

\subsection{Assessment of Organic Acids}

The juice $(25 \mathrm{~g}$ ) was homogenized with $25 \mathrm{ml}$ of $4.5 \%$ (w/v)metaphosphoric acid solution and filtered through a $0.45 \mu \mathrm{m}$ pore size nylon membrane filter (Polydera et al., 2005). The filtrate was analyzed for organic acids by high-performance liquid chromatography (HPLC) (Model 1100 Series, Agilent, Germany), equipped with C18 column $(4.6 \times 250 \mathrm{~mm}, 5 \mu \mathrm{m}$, Restek, Germany) and visible wavelength detector (VWD) at $210 \mathrm{~nm}$. Column temperature was $35^{\circ} \mathrm{C}$ and $50 \mathrm{mMortho-phosphoric} \mathrm{acid} \mathrm{was} \mathrm{used} \mathrm{as} \mathrm{mobile} \mathrm{phase} \mathrm{at} \mathrm{a} \mathrm{flow} \mathrm{rate} 0.5$ $\mathrm{ml} / \mathrm{min}$ (Aarabi et al., 2008). Standards of citric acid and malic acid were prepared in $0.05 \%(\mathrm{w} / \mathrm{v})$ metaphosphoric acid. HPLC samples were run in triplicate for each replication and averaged.

\subsection{Fractionation of Juice Sac Cells and Enzyme Assays}

Juice vesicles of tangerine fruit were fractionated into cytosolic or soluble fraction and a crude fraction enriched with mitochondria as described by Sadka et al. (2000a) with slight modifications. Citrate synthase activity was determined by using Ellman's reagent [5,5'-dithiobis-(2-nitrobenzoic acid), DTNB]. The assay mixture was $1,500 \mu \mathrm{l}$ and total volume composed of $0.2 \mathrm{mM}$ acetyl-CoA, $0.5 \mathrm{mM}$ oxaloacetate and $0.1 \mathrm{mM}$ DTNB in 50 mMTris- $\mathrm{HCl}(\mathrm{pH}$ 7.8). The reaction was started by adding 20-50 $\mu \mathrm{l}$ of the extracted enzyme. The reaction product thionitrobenzoic acid (TNB) was the absorbing substance with intense absorption at $412 \mathrm{~nm}, 30^{\circ} \mathrm{C}$ (Kuznetsov et al., 2006). Aconitase activity was determined using 1,500 $\mu$ l, mixture composed of 40 mMTris- $\mathrm{HCl}(\mathrm{pH} 7.5), 100 \mathrm{mMNaCl}$ and $0.2 \mathrm{mMcis}$-aconitic acid. The reaction was started by adding $50-100 \mu 1$ of the extracted enzyme, and the declining of cis-aconitic acid was followed by measuring the absorbance at 240 $\mathrm{nm}, 25^{\circ} \mathrm{C}$ (Hirai \& Ueno, 1977). NADP-IDH activity was performed in $1,500 \mu \mathrm{l}$ reaction mixture composed of $25 \mathrm{mMTris}-\mathrm{HCl}$ (pH 7.5), $0.5 \mathrm{mMDL}$-isocitric acid, $1 \mathrm{mM}$ B-NADP and $5 \mathrm{mM} \mathrm{MgSO}_{4}$. The reaction was started by adding $20-50 \mu \mathrm{l}$ of the extracted enzyme. The recorded increase in production of NADPH at absorbance 340 $\mathrm{nm}, 37^{\circ} \mathrm{C}$ was carried out (Kubo et al., 2002). All three enzymes activities were determined in duplicate for each replication and averaged. The protein content of the fractionated extracts were quantified according to the dye-binding assay at the absorbance of $595 \mathrm{~nm}$ (Bradford, 1976) in triplicate for each replication and averaged.

\subsection{Statistical Analysis}

All data were analyzed by analysis of variance (ANOVA) using SPSS version 14 and the differences between harvesting periods and cultivars were analyzed by a Least Significant Difference (LSD) comparison. The level of significant difference was indicated with the following: $\mathrm{P}<0.05$ for all comparisons. 


\section{Results and Discussion}

\subsection{Changes in Fruit Size and Weight}

The increases in fruit size (diameter at the equatorial axis) and weight showed similar patterns between the two tangerine cultivars (Figure 1A-B). The changes in fruit size and weight increased in a linear fashion during growth periods (16-34 WAF) and remained constant during maturation periods (35-37 WAF). There was no significantly different ( $p>0.05$ ) for either size or weight between 'Sai Num Phueng' and 'See Thong' cultivars. The changes in fruit size and weight agreed with the general morphological characteristics of citrus fruit (Spiegel-Roy \& Goldschmidt, 1996). The duration of fruit development varied according to cultivar, climate, etc. (Baldwin, 1993). Normally, mandarin and tangerine ripen 9 to 10 months after anthesis (Baldwin, 1993).

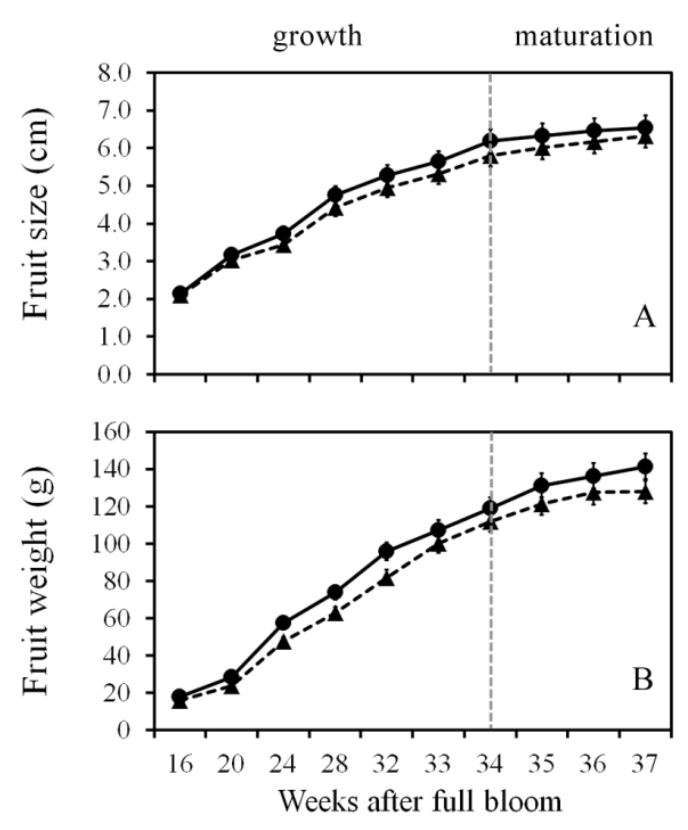

Figure 1. Changes in fruit size (A) and weight (B) during growth and maturation of two tangerine cultivars, 'Sai Num Phueng' $(\bullet)$ and 'See Thong' $(\boldsymbol{\Delta})$

\subsection{Changes in TSS, TA and Organic Acids}

TSS of both cultivars continually increased during growth (16-34 WAF) and then slowly increased during maturation (35-38 WAF). At commercial harvest 37 WAF, TSS was $11.38 \%$ for 'Sai Num Phueng' and 11.10\% for 'See Thong'. There was no significant difference $(\mathrm{p}>0.05)$ in TSS between the two tangerine cultivars during growth. Then, TSS of 'Sai Num Phueng' became higher than 'See Thong' during maturation (Figure 2A).

TA of both cultivars increased and reached a peak for 16-24 WAF with 4.68 and 3.99\% of citric acid per $100 \mathrm{~g}$ juice, respectively at $24 \mathrm{WAF}$. Then, TA rapidly decreased for 28-34 WAF and slightly decreased during maturation (35-37 WAF). At commercial harvest $37 \mathrm{WAF}$, TA of 'Sai Num Phueng' and 'See Thong' was0.86 and $0.69 \%$, respectively. TA of 'Sai Num Phueng' was significantly higher $(\mathrm{p} \leq 0.05)$ than 'See Thong' throughout fruit development (Figure 2B).

Citric acid content showed similar patterns of the two tangerine cultivars. During growth, citric acid content of 'Sai Num Phueng' and 'See Thong' cultivars increased for 16-24 WAF which reached the highest peaks at 45.51 and $38.09 \mathrm{mg} \mathrm{g}^{-1}$ juice, respectively at $24 \mathrm{WAF}$, and then sharply decreased for 28-34 WAF. This content slowly declined during maturation to 9.12 and $6.52 \mathrm{mg} \mathrm{g}^{-1}$ juice, respectively at commercial harvest 37 WAF. Citric acid content of 'Sai Num Phueng' was significantly greater $(p \leq 0.05)$ than that of 'See Thong' throughout fruit development (Figure 2C, Table 1 and 2). 

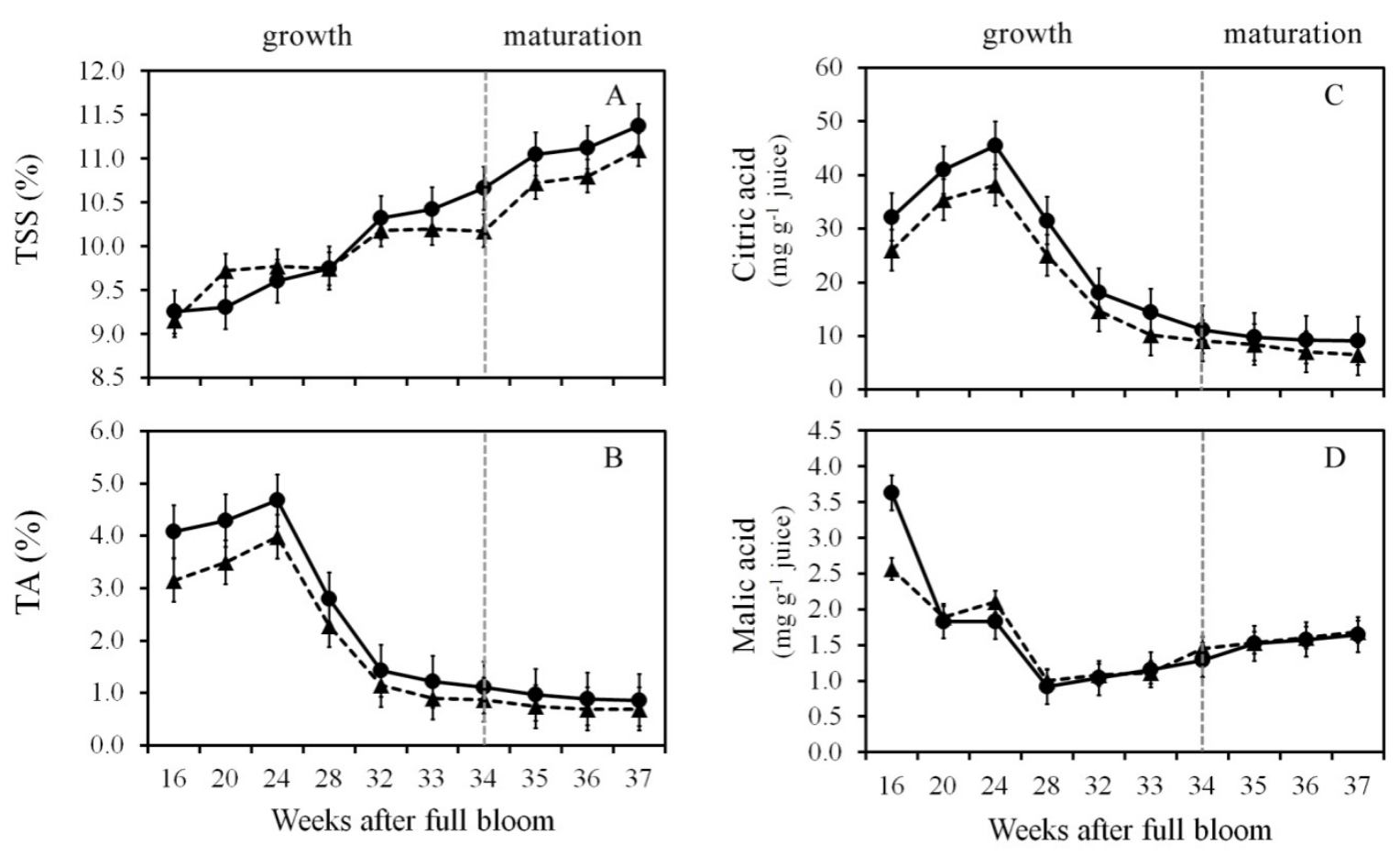

Figure 2. Changes in TSS (A), TA (B), citric acid content (C) and malic acid content (D) during growth and maturation of two tangerine cultivars, 'Sai Num Phueng' $(\bullet)$ and 'See Thong' $(\boldsymbol{\Delta})$

Table 1. Changes in enzyme activities in juice vesicle during growth and maturation of tangerine fruit, 'Sai Num Phueng' cultivar

\begin{tabular}{ccccccc}
\hline $\begin{array}{c}\text { 'Sai Num } \\
\text { Phueng' }\end{array}$ & & $\begin{array}{c}\text { Citric acid } \\
\left(\mathrm{mg} \mathrm{g}^{-1} \text { juice }\right)\end{array}$ & \multicolumn{3}{c}{ Enzyme activity(unit mg ${ }^{-1}$ protein) } \\
\hline Stages & WAF & & $\begin{array}{c}\text { Mitochondrial } \\
\text { citrate synthase }\end{array}$ & $\begin{array}{c}\text { Mitochondrial } \\
\text { aconitase }\end{array}$ & $\begin{array}{c}\text { Cytosolic } \\
\text { aconitase }\end{array}$ & $\begin{array}{c}\text { Cytosolic } \\
\text { NADP-IDH }\end{array}$ \\
\hline Growth & 16 & $32.20 \pm 0.14^{\mathrm{c}}$ & $4.17 \pm 0.15^{\mathrm{bc}}$ & $4.75 \pm 0.23^{\mathrm{a}}$ & $1.70 \pm 0.07^{\mathrm{h}}$ & $0.15 \pm 0.07^{\mathrm{f}}$ \\
& 20 & $40.95 \pm 0.04^{\mathrm{b}}$ & $4.31 \pm 0.12^{\mathrm{bc}}$ & $4.35 \pm 0.20^{\mathrm{b}}$ & $2.63 \pm 0.10^{\mathrm{fg}}$ & $0.16 \pm 0.02^{\mathrm{f}}$ \\
& 24 & $45.51 \pm 0.20^{\mathrm{a}}$ & $5.32 \pm 0.21^{\mathrm{a}}$ & $2.06 \pm 0.15^{\mathrm{c}}$ & $4.59 \pm 0.29^{\mathrm{d}}$ & $0.66 \pm 0.03^{\mathrm{d}}$ \\
& 28 & $31.50 \pm 0.18^{\mathrm{c}}$ & $4.64 \pm 0.11^{\mathrm{bc}}$ & $0.85 \pm 0.23^{\mathrm{d}}$ & $11.56 \pm 0.12^{\mathrm{b}}$ & $1.26 \pm 0.09^{\mathrm{a}}$ \\
& 32 & $18.10 \pm 0.13^{\mathrm{d}}$ & $4.15 \pm 0.19^{\mathrm{cd}}$ & $0.77 \pm 0.16^{\mathrm{de}}$ & $13.44 \pm 0.22^{\mathrm{a}}$ & $1.26 \pm 0.13^{\mathrm{a}}$ \\
& 33 & $14.40 \pm 0.01^{\mathrm{e}}$ & $3.75 \pm 0.03^{\mathrm{de}}$ & $0.74 \pm 0.10^{\mathrm{de}}$ & $13.49 \pm 0.20^{\mathrm{a}}$ & $1.12 \pm 0.15^{\mathrm{b}}$ \\
& 34 & $11.18 \pm 0.04^{\mathrm{f}}$ & $3.71 \pm 0.09^{\mathrm{e}}$ & $0.70 \pm 0.04^{\mathrm{e}}$ & $12.42 \pm 0.24^{\mathrm{b}}$ & $0.82 \pm 0.06^{\mathrm{c}}$ \\
Maturation & 35 & $9.82 \pm 0.09^{\mathrm{g}}$ & $3.51 \pm 0.13^{\mathrm{e}}$ & $0.81 \pm 0.12^{\mathrm{e}}$ & $5.99 \pm 0.15^{\mathrm{c}}$ & $0.60 \pm 0.04^{\mathrm{d}}$ \\
& 36 & $9.31 \pm 0.19^{\mathrm{h}}$ & $2.64 \pm 0.07^{\mathrm{f}}$ & $0.77 \pm 0.26^{\mathrm{e}}$ & $3.77 \pm 0.16^{\mathrm{de}}$ & $0.42 \pm 0.02^{\mathrm{e}}$ \\
& 37 & $9.12 \pm 0.14^{\mathrm{h}}$ & $2.82 \pm 0.07^{\mathrm{f}}$ & $0.78 \pm 0.06^{\mathrm{e}}$ & $3.21 \pm 0.19^{\mathrm{ef}}$ & $0.24 \pm 0.04^{\mathrm{f}}$ \\
\hline LSD $_{0.05}$ & & 1.04 & 0.44 & 0.40 & 0.88 & 0.13 \\
C.V. (\%) & & 2.97 & 6.98 & 15.12 & 7.66 & 11.73 \\
\hline
\end{tabular}

As shown in Table 1,means within the same column followed by different letters are significantly different at $\mathrm{P} \leq 0.05$ level by Least Significant Difference (LSD) comparison. Data are mean values $\pm \mathrm{SD} / \mathrm{SQRT}$. 
Table 2. Changes in enzyme activities in juice vesicle during growth and maturation of tangerine fruit, 'See Thong' cultivar

\begin{tabular}{ccccccc}
\hline 'See Thong' & & $\begin{array}{c}\text { Citric acid } \\
\left(\mathrm{mg} \mathrm{g}^{-1} \text { juice }\right)\end{array}$ & \multicolumn{3}{c}{ Enzyme activity(unit mg protein $^{-1}$} \\
\hline \multirow{2}{*}{ Stages } & WAF & & $\begin{array}{c}\text { Mitochondrial } \\
\text { citrate synthase }\end{array}$ & $\begin{array}{c}\text { Mitochondrial } \\
\text { aconitase }\end{array}$ & $\begin{array}{c}\text { Cytosolic } \\
\text { aconitase }\end{array}$ & $\begin{array}{c}\text { Cytosolic } \\
\text { NADP-IDH }\end{array}$ \\
Growth & 16 & $26.03 \pm 0.12^{\mathrm{c}}$ & $4.16 \pm 0.13^{\mathrm{c}}$ & $5.09 \pm 0.08^{\mathrm{a}}$ & $2.63 \pm 0.29^{\mathrm{fg}}$ & $0.23 \pm 0.06^{\mathrm{f}}$ \\
& 20 & $35.44 \pm 0.14^{\mathrm{b}}$ & $4.83 \pm 0.07^{\mathrm{b}}$ & $4.64 \pm 0.09^{\mathrm{b}}$ & $2.86 \pm 0.39^{\mathrm{fg}}$ & $0.25 \pm 0.02^{\mathrm{f}}$ \\
& 24 & $38.09 \pm 0.01^{\mathrm{a}}$ & $5.24 \pm 0.06^{\mathrm{a}}$ & $2.73 \pm 0.10^{\mathrm{c}}$ & $6.14 \pm 0.32^{\mathrm{e}}$ & $1.04 \pm 0.04^{\mathrm{c}}$ \\
& 28 & $25.11 \pm 0.03^{\mathrm{d}}$ & $4.79 \pm 0.09^{\mathrm{b}}$ & $1.11 \pm 0.15^{\mathrm{d}}$ & $16.45 \pm 0.31^{\mathrm{ab}}$ & $1.30 \pm 0.06^{\mathrm{b}}$ \\
& 32 & $14.73 \pm 0.02^{\mathrm{e}}$ & $4.10 \pm 0.04^{\mathrm{cd}}$ & $0.96 \pm 0.03^{\mathrm{de}}$ & $17.93 \pm 0.60^{\mathrm{ab}}$ & $1.56 \pm 0.17^{\mathrm{a}}$ \\
& 33 & $10.23 \pm 0.05^{\mathrm{f}}$ & $3.86 \pm 0.10^{\mathrm{d}}$ & $0.87 \pm 0.18^{\mathrm{e}}$ & $15.84 \pm 0.40^{\mathrm{bc}}$ & $1.52 \pm 0.06^{\mathrm{a}}$ \\
& 34 & $9.15 \pm 0.15^{\mathrm{g}}$ & $3.95 \pm 0.07^{\mathrm{cd}}$ & $0.81 \pm 0.06^{\mathrm{e}}$ & $13.93 \pm 0.36^{\mathrm{c}}$ & $1.04 \pm 0.02^{\mathrm{c}}$ \\
Maturation & 35 & $8.48 \pm 0.04^{\mathrm{h}}$ & $3.11 \pm 0.17^{\mathrm{e}}$ & $0.83 \pm 0.02^{\mathrm{e}}$ & $8.83 \pm 0.25^{\mathrm{d}}$ & $0.80 \pm 0.05^{\mathrm{d}}$ \\
& 36 & $7.05 \pm 0.01^{\mathrm{i}}$ & $3.03 \pm 0.02^{\mathrm{e}}$ & $0.81 \pm 0.09^{\mathrm{e}}$ & $4.36 \pm 0.55^{\mathrm{ef}}$ & $0.43 \pm 0.03^{\mathrm{e}}$ \\
& 37 & $6.52 \pm 0.01^{\mathrm{i}}$ & $2.93 \pm 0.01^{\mathrm{e}}$ & $0.83 \pm 0.14^{\mathrm{e}}$ & $3.43 \pm 0.40^{\mathrm{fg}}$ & $0.25 \pm 0.04^{\mathrm{f}}$ \\
\hline LSD $_{0.05}$ & & 0.54 & 0.30 & 0.22 & 0.96 & 0.13 \\
C.V.(\%) & & 1.90 & 1.52 & 7.33 & 13.81 & 10.01 \\
\hline
\end{tabular}

As shown in Table 2, means within the same column followed by different letters are significantly different at $\mathrm{P} \leq 0.05$ level by Least Significant Difference (LSD) comparison. Data are mean values $\pm \mathrm{SD} / \mathrm{SQRT}$.

Malic acid content of both cultivars was very high and significantly different $(p \leq 0.05)$ at early growth stage with $3.63 \mathrm{mg} \mathrm{g}^{-1}$ juice for 'Sai Num Phueng' and $2.56 \mathrm{mg} \mathrm{g}^{-1}$ juice for 'See Thong' at 16 WAF. Thereafter, this content declined and remained almost constant at low levels and did not significantly differ $(\mathrm{p}>0.05)$ for both cultivars during maturation (1.52-1.69 $\mathrm{mg} \mathrm{g}^{-1}$ juice) (Figure 2D).

Organic acids were usually used as respiratory substrates for synthesis of ATP in TCA cycle (Ting \& Attaway, 1971) and also played an important role in the consumer perception of fruit flavor quality (Chen et al., 2009). The decreases in citric and malic acid contents of both tangerine cultivars during maturation were in agreement withthe general observation in almost citrus fruit (Ladaniya, 2008) such as Navel orange (Iglesias et al., 2007) and 'Clementina' mandarin (Cercos et al., 2006). The declinesin organic acid contents could be partly associated with the increases in fruit size and water content (Ting \& Attaway, 1971). It might be due to the used for energy production through cellular respiration (Purvis, 1983) and the conversion of organic acids to sugar (glucose) through gluconeogenesis (Echeverria \& Burns, 1989).

\subsection{Changes in Activities of Citric Acid Metabolizing Enzymes}

Citrate synthase activity was detected only in mitochondrial fraction. Aconitase activity was detected in both mitochondrial and cytosolic fractions. NADP-isocitrate dehydrogenase (NADP-IDH) activity was detected in cytosolic fraction. The changes in mitochondrial citrate synthase activity patterns in both tangerine cultivars were almost similar throughout fruit development (Figure 3A). At early growth stage (16-24 WAF), mitochondrial citrate synthase activity of 'Sai Num Phueng' and 'See Thong' cultivars increased and reached

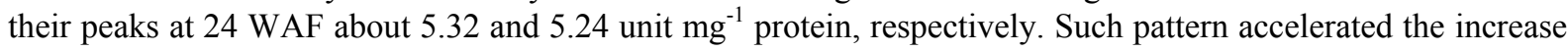
in citric acid content. Subsequently, the same activity continually decreased toward fruit maturation (28-37 WAF) to about 2.82 and 2.93 unit $\mathrm{mg}^{-1}$ protein, respectivelyat commercial harvest $37 \mathrm{WAF}$. These paralleled the decrease in citric acid content (Tables 1 and 2).

The changes in aconitase activity in mitochondrial fraction showed similar patterns between 'Sai Num Phueng' and 'See Thong' cultivars throughout fruit development (Figure 3B). At early growth stage (16-24 WAF), mitochondrial aconitase activity of both cultivars significantly decreased $(p \leq 0.05)$ which coincided with the high level of citric acid content. Subsequently, the same activity remained relatively constant at the low level for 28-37 WAF. At 16 WAF, 'Sai Num Phueng' and 'See Thong' cultivars had quite high level of mitochondrial 


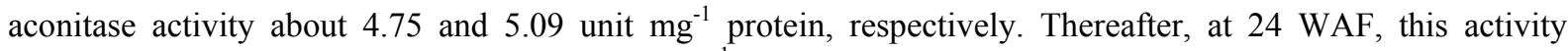

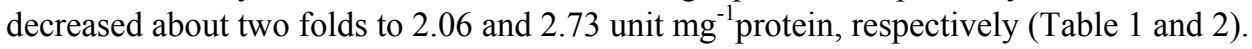

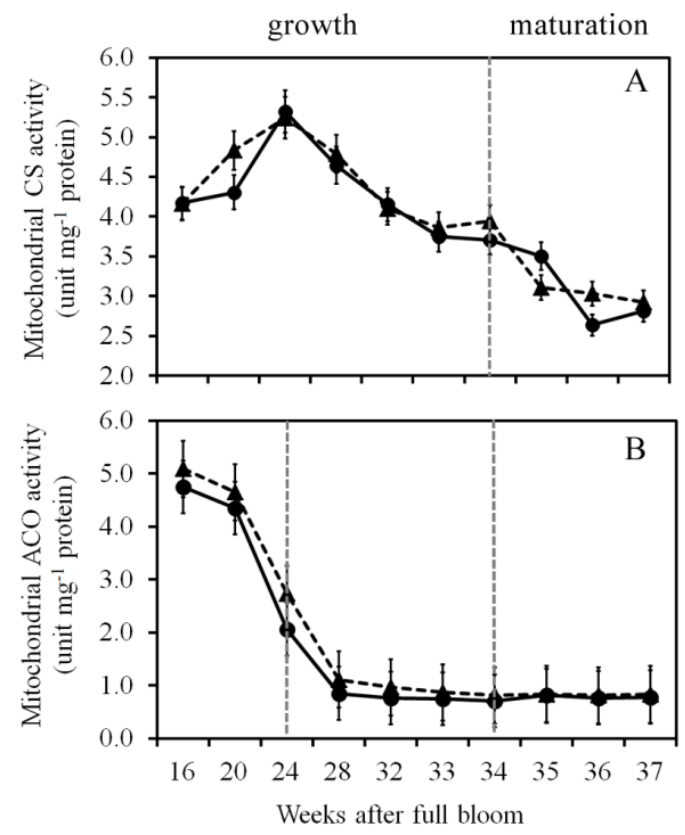

Figure 3. Changes in activities of citrate synthase (CS, A) and aconitase (ACO, B) in mitochondrial fraction during growth and maturation of two tangerine cultivars, 'Sai Num Phueng' $(\bullet)$ and 'See Thong' ( $\mathbf{A})$

Aconitase and NADP-IDH activities in cytosolic fraction showed similar patterns between 'Sai Num Phueng' and 'See Thong' cultivars throughout fruit development (Figure 4A-B). Cytosolic aconitase and NADP-IDH activities of both cultivars were relatively low at early growth stage (16-24 WAF). Thereafter, these activities dramatically increased and remained constant at relatively high levels for 28-34 WAF and were accompanied with the reduction in citric acid content. When the fruit entered the maturation stage (35-37 WAF), these activities sharply decreased about three folds between week $34^{\text {th }}$ to $35^{\text {th }}$, then remained relatively constant at low levels until commercial harvest at $37 \mathrm{WAF}$ while citric acid content slightly decreased. At $24 \mathrm{WAF}$, 'Sai Num

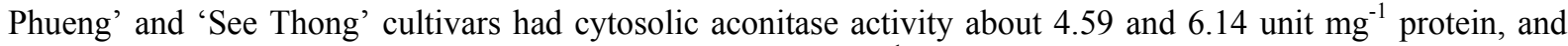
cytosolic NADP-IDH activity about 0.66 and 1.04 unit $\mathrm{mg}^{-1}$ protein, respectively. At $28 \mathrm{WAF}$, cytosolic aconitase activity increased about three folds to 11.56 and 16.45 unit $\mathrm{mg}^{-1}$ protein, respectively and cytosolic NADP-IDH activity increased about two folds to 1.26 and 1.30 unit mg $^{-1}$ protein, respectively (Tables 1 and 2).

Citrate synthase activity was detected only in mitochondria fraction, which similar to the reports in sour lemon and 'Shamouti' orange (Sadka et al., 2001). Aconitase activity was detected in both mitochondria and cytosolic fractions. The similar result was observed in sour lemon and sweet lime(Sadka et al., 2000a; Sadka et al., 2000b). NADP-IDH activities were detected in cytosolic fraction, which agreed to the report in sour lemon (Sadka et al., 2000b). In citrus fruit, citric acid was synthesized in the juice sac cells which took place in the mitochondria [through the TCA cycle] (Ramakrishnan, 1971). The synthesis occurred when citrate synthase condensed acetyl-CoA with oxaloacetic acid to yield citric acid (Sadka et al., 2001). The citric acid was then translocated to accumulate in the vacuoles of juice sac cells, where it reached high concentrations (Echeverria \& Valich, 1988).In present study, the induction of citrate synthase activity and the reduction of aconitase activity in mitochondrial fraction, which accelerated the increase in citric acid content at early growth stage (16-24 WAF) of the two tangerine cultivars. Thus, it could be concluded that citrate synthase and aconitase enzymes in the mitochondria were essential in citric acid accumulation at early growth stage of tangerine fruit. The increase in citrate synthase activity was important for citric acid synthesis and its accumulation in citrus fruit (Kubo et al., 2002). Sadka et al. (2000a) reported the same that in young sour lemon, the decrease of aconitase activity in mitochondria played a direct role in citric acid accumulation. 


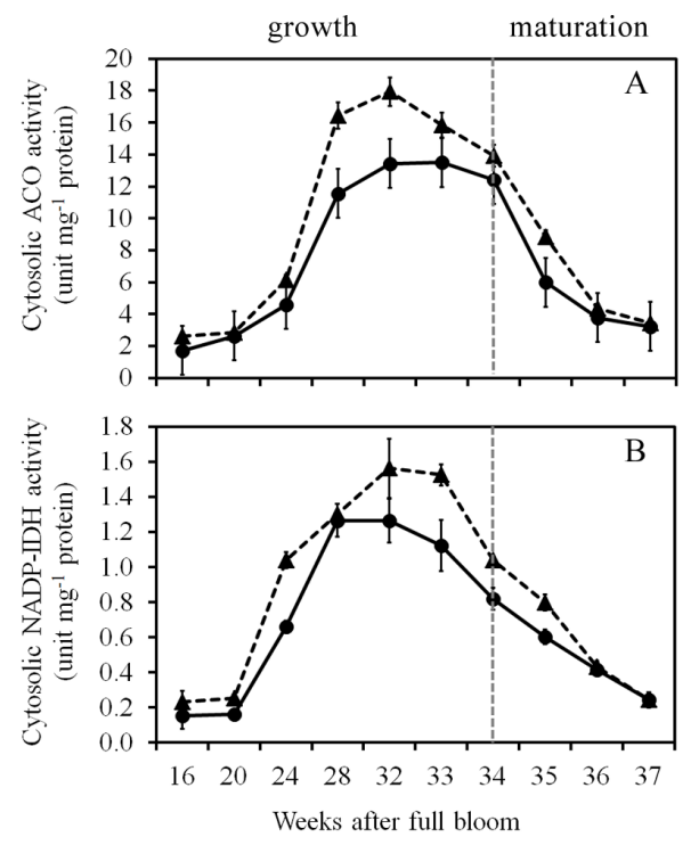

Figure 4. Changes in activities of aconitase (A) and NADP-IDH (B) in cytosolic fraction during growth and maturation of two tangerine cultivars, 'Sai Num Phueng' $(\bullet)$ and 'See Thong' $(\mathbf{A})$

When citric acid declined inlemon fruit, it was mobilized from the vacuole to the cytosol and aconitase activity was responsible for the conversion of citric acid into isocitric acid in the cytosol (Sadka et al., 2000a). Isocitric acid was then oxidized by NADP-IDH to yield $\alpha$-ketoglutaric acid in the cytosol (Sadka et al., 2000b). The results found that the dramatic increase of aconitase activity in cytosolic fraction which accompanied the reduction in citric acid content of both tangerine cultivars for 28-34 WAF. During maturation (35-37 WAF), the same enzymes activity decreased to the low level, which coincided with the slight decrease in citric acid content. NADP-IDH activity increased paralleled with the increase in aconitase activity in cytosolic fraction of two tangerine cultivars. Therefore, enzyme aconitase in the cytosol likely played a key role in the reduction of citric acid during growth and maturation of tangerine fruit. NADP-IDH could be consisted with aconitase for enhancement the reduction of citric acid in the cytosol. This was agree with the report forSatsuma mandarin (Hirai \& Ueno, 1977), sour lemon (Sadka et al., 2000a) and lemon (Citrus limon L. Burm) (Luo et al., 2003). In the immature Satsuma mandarin, aconitase activity rapidly increased about four folds, while citric acid sharply declined (Hirai \& Ueno, 1977). Sadka et al. (2000a) reported the same result that the re-induction of aconitase activity in cytosol preceded citric acid decline toward maturation of sour lemon. NADP-IDH played a role in glutamic acid synthesis from 2-oxoglutaric acid in the cytosol of plant cells (Chen et al., 2009). Sadka et al. (2000b) reported that, NADP-IDH activity increased in the cytosol, while citric acid started to decrease in lemon and suggested that the conversion of citric acid to glutamic acid via isocitric acid and 2-oxoglutaric acid might be a continuous process, which took place in the cytosol.

\subsection{A comparison of Enzyme Activities from 'Sai Num Phueng' and 'See Thong' Cultivars}

There was no significant difference $(\mathrm{p}>0.05)$ in citrate synthase activity in mitochondria fraction between both cultivars throughout fruit development (Figure 3A). While citric acid content of 'Sai Num Phueng' was higher than that of 'See Thong' (Figure 2C). At early growth stage (16-24 WAF), Sai Num Phueng'cultivar had significantly lower $(\mathrm{p} \leq 0.05)$ aconitase activityin mitochondria fraction than 'See Thong' cultivar. Thereafter, there was no difference in the same activity between the two tangerine cultivars (Figure 3B). Aconitase and NADP-IDH activities in cytosolic fraction of 'Sai Num Phueng' were significantly lower ( $\mathrm{p} \leq 0.05)$ in comparison with'See Thong' cultivar for 16-35 WAF. Then, these activities in cytosolic fractiondid not differfor both cultivars (Figure 4A-B, Tables 1 and 2). Sadka et al. (2000a) suggested that aconitase activity was decreased only in sour lemon but not in sweet lime, and this contributed to the different level of citric acid accumulation. However, the comparison in NADP-IDH activity between citrus cultivars has never been reported. Sadka et al. (2001) suggested that the difference in acid accumulation between acid-less and acid-containing fruits might not be attributed to the changes in the activity of citrate synthase. Therefore, the difference in the level of aconitase 
activity could account for the difference in citric acid content between the two tangerine cultivars. However, citrate synthase might not have a relationship for citric acid content in different tangerine cultivar.

\section{Conclusion}

The results in this study can be concluded that citrate synthase and aconitase enzymes in the mitochondria were essential in citric acid accumulation at early growth stage of tangerine fruit. Aconitase in the cytosol played a key role in the reduction of citric acid during growth and maturation. NADP-IDH could be consisted with aconitase for enhancement the reduction of citric acid content in the cytosol. Aconitasecould account for the difference in citric acid content between 'Sai Num Phueng' and 'See Thong' cultivars.

\section{Acknowledgments}

We thank the Office of the Higher Education Commission, Thailand, for supporting the grant fund under the program Strategic Scholarships for Frontier Research Network for the Ph.D. Program Thai Doctoral degree for this research. We also thank the Postharvest Technology Research Institute, Chiang Mai University, Thailand for their support. All tangerine fruit were supplied from Chiang Mai Thanathon Co., Ltd, Thailand. The authors would like to thank Dr. Elizabeth A. Baldwin (Citrus and Subtropical Products Research Unit, USDA-ARS, Fort Pierce, FL) for reviewing the manuscript.

\section{References}

Aarabi, A., Barzegar, M., \& Azizi, M. H. (2008). Effect of cultivar and cold storage of pomergranate (Punica granatum L.) juices on organic acid composition. Asean Food Journal, 15(1), 45-55.

AOAC. (2005). Official methods of analysis of AOAC International (18th Ed.). Maryland, MD: Association of Official Analytical Chemists.

Baldwin, E. A. (1993). Citrus fruit. In G. B. Seymour, J. E. Taylor \& G. A. Tucker (Eds.), Biochemistry of Fruit Ripening (pp. 107-149). Cambridge, England: Great Britain at the University Press.

Bradford, M. M. (1976). A rapid and sensitive method for the quantitation of microgram quantities of protein utilizing the principle of protein-dye binding. Analytical Biochemistry, 72, 248-254.

Cercos, M., Soler, G., Iglesias, D. J., Gadea, J., Forment, J., \& Talon, M. (2006). Global analysis of gene expression during development and ripening of citrus fruit flesh. A proposed mechanism for citric acid utilization. Plant Molecular Biology, 62, 513-527. http://dx.doi.org/10.1007/s11103-006-9037-7

Chen, F., Liu, X., \& Chen, L. (2009). Developmental changes in pulp organic acid concentration and activities of acid-metabolising enzymes during the fruit development of two loquat (Eriobotrya japonica Lindl.) cultivars differing in fruit acidity. Food Chemistry, 114(2), 657-664. http://dx.doi.org/10.1016/j.foodchem.2008.10.003

Echeverria, E., \& Burns, J. K. (1989). Vacuolar acid hydrolysis as a physiological mechanism for sucrose breakdown. Plant Physiology, 90, 530-533.

Echeverria, E., \& Valich, J. (1988). Carbohydrate and enzyme distribution in protoplasts from valencia orange juice sacs. Phytochemistry, 27(1), 73-76. http://dx.doi.org/10.1016/0031-9422(88)80593-4

Hirai, M., \& Ueno, I. (1977). Development of citrus fruits: Fruit development and enzymatic changes in juice vesicle tissue. Plant and Cell Physiology, 18, 791-800.

Iglesias, D. J., Cercós, M., Colmenero-Flores, J., Naranjo, M., Ríos, G., Carrera, E. (2007). Physiology of citrus $\begin{array}{llll}\text { fruiting. Brazilian Journal of Plant Physiology, 19(4), 333-362. } & \end{array}$ http://dx.doi.org/10.1590/S1677-04202007000400006

Kubo, T., Kihara, T., \& Hirabayashi, T. (2002). The effects of spraying lead arsenate on citrate accumulation and the related enzyme activities in the juice sacs of Citrusnatsudaidai. Journal of the Japanese Society for Horticultural Science, 71(3), 305-310.

Kuznetsov, A. V., Lassnig, B., \& Gnaiger, E. (2006). Laboratory protocol citrate synthase mitochondrial marker enzyme. Mitochondrial Physiology Network, 8(14), 1-8.

Ladaniya, M. S. (2008). Citrus Fruit Biology Technology and Evaluation. San Diego: Academic Press. http://dx.doi.org/10.1078\%2F1439-6092-00058

Lobit, P., Geanard, M., Wu, B. H., Soing, P., \& Habib, R. (2003). Modelling citrate metabolism in fruits: responses to growth and temperature. Journal of Experimental Botany, 54(392), 2489-2501. http://dx.doi.org/10.1093/jxb/erg264 
Luo, A., Yang, X., Deng, Y., Li, C., Xiang, K., \& Li, D. (2003). Organic acid concentrations and the relative enzymatic changes during the development of citrus fruits. Scientia Agricultura Sinica, 36, 941-944. http://dx.doi.org/10.5897/AJAR11.582

Office of Comercial Affairs Chiang Mai. (2008). Orange situation in Chiang Mai, crop year 2008/2009 (p. 30). Ministry of commerce Thailand, Chiangmai, Thailand.

Polydera, A. C., Stoforos, N. G., \& Taoukis, P. S. (2005). Quality degradation kinetics of pasteurised and high pressure processed fresh Navel orange juice: Nutritional parameters and shelf life. Innovative Food Science \& Emerging Technologies, 6(1), 1-9. http://dx.doi.org/10.1016/j.ifset.2004.10.004

Purvis, A. C. (1983). Moisture loss and juice quality from waxed and individually sealed-packaged Citrus fruil. Journal of the American Society for Horticultural Science, 96, 327-329.

Ramakrishnan, C. V. (1971). Citric acid metabolism in the fruit tissues of Citrus acida. Current Science, 5, 97-100.

Sadka, A., Dahan, E., Cohen, L., \& Marsh, K. B. (2000a). Aconitase activity and expression during the

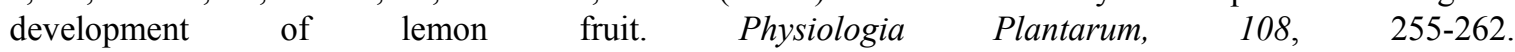
http://dx.doi.org/10.1034/j.1399-3054.2000.108003255.x

Sadka, A., Dahan, E., Etti, O., \& Cohen, L. (2000b). NADP ${ }^{+}$-isocitrate dehydrogenase gene expression and isozyme activity during citrus fruit development. Plant Science, 158, 173-181. http://dx.doi.org/10.1016/S0168-9452(00)00328-9,

Sadka, A., Dahan, E., Or, E., Roose, M. L., Marsh, K. B., \& Cohen, L. (2001). Comparative analysis of mitochondrial citrate synthase gene structure, transcript level and enzymatic activity in acidless and acid-containing Citrus varieties. Australian Journal of Plant Physiology, 28, 383-390. http://dx.doi.org/10.1071/PP00136

Saradhuldhat, P., \& Paull, R. E. (2007). Pineapple organic acid metabolism and accumulation during fruit development. Scientia Horticulturae, 112, 297-303. http://dx.doi.org/10.1016/j.scienta.2006.12.031

Spiegel-Roy, P., \& Goldschmidt, E. E. (1996). Biology of citrus. London, England: Cambridge University Press.

Sweetman, C., Delucb, L. G., Cramerb, G. R., Fordc, C. M., \& Soolea, K. L. (2009). Regulation of malate $\begin{array}{llll}\text { metabolism in grape berry. Phytochemistry, } & \text { 70(11-12), } & \text { 1329-1344. }\end{array}$ http://dx.doi.org/10.1016/j.phytochem.2009.08.006

Tang, M., Bie, Z., Wu, M., Yi, H., \& Feng, J. (2010). Changes in organic acids and acid metabolism enzymes in melon fruit during development. Scientia Horticulturae, 123, 360-365. http://dx.doi.org/10.1016/j.scienta.2009.11.001

Ting, S. V., \& Attaway, J. A. (1971). Citrus fruits. In A. C. Hulme (Ed.), The Biochemistry of Fruit and Their Products (pp. 107-169). London, England: Academic Press. 